Title: DOES FACETED DISPLAY IN A LIBRARY CATALOG INCREASE USE OF SUBJECT HEADINGS? Authors: Kathleen Bauer, Alice Peterson-Hart

Abstract: Article presents a comparison of patron use of two interfaces to the Yale Library catalog: faceted (Yufind) and non-faceted (Orbis). The authors explored if the use of subject headings would be greater in Yufind than Orbis due to facets. From January to May 2011 subject facets were used in 5.1\% of all Yufind searches while In Orbis subject headings were used in 6.4\% of searches. Facets led to less use of subject headings than following links in records in either interface. Searches were initiated more often in Orbis than Yufind (8.2 times) and most often Yufind sessions started in Google. 


\section{DOES FACETED DisPlay IN A LIBRARY CATALOG INCREASE USE OF SUBJECT HEADINGS?}

\section{ABSTRACT}

Libraries deploy Library of Congress subject headings as a way to make material discoverable by topics, but have faced declining use of subject headings by patrons. Librarians have recognized that catalog interfaces are not helpful in encouraging use of subject headings and, in response, libraries have implemented next generation catalogs, which feature faceted display of search results as a way to improve discoverability of collection material. In theory, faceted display should improve patrons' search experience and make it easier for them to find relevant material. Subject headings are typically included in faceted display, but the use of subject headings in facets has been little studied. The objectives of this case study at Yale University were to answer these questions: When presented with subject heading facets, would patrons use them? What problems would patrons have using facets successfully? Would use of subject headings in the faceted display be greater than use in a non-faceted display?

To answer these questions the authors employed usability testing of a faceted catalog and log file analysis of use of both faceted and non-faceted catalogs. Usability testing provided qualitative information about patron search behavior, intentions and attitudes toward facets in a controlled test setting, and log file analysis added quantitative evidence about how much facets were used in real search activity.

In early usability testing faceted display showed promise as a way to promote use of catalog metadata. A faceted catalog (Yufind) was run alongside non-faceted catalog (Orbis) from January to May 2011. In Yufind subject facets were used in 5.1\% of all searches, while subject heading links in records were used more often (23.5\%). In non-faceted search subject headings were used in $6.4 \%$ of all searches. Patrons used subject heading facets less than subject heading links in records in 
either interface. Searches were initiated more often in the non-faceted display (8.2 times as often). Patrons were more likely to start a Yufind session by searching in Google, discovering Yufind records there and then moving to Yufind.

\section{PROBLEM STATEMENT}

Libraries have experienced decreasing use of subject headings in patrons' searches. At the same time librarians see faceted display proving successful in a variety of e-commerce search interfaces. They have concluded that traditional OPAC displays are not sufficient for exposing the metadata in the catalog, and that faceted display will lead to more use of metadata and thus better discovery. No study has been done seeking to determine if facets might drive greater use of specific types of metadata including subject headings.

The authors wanted to understand the following about search behavior in a faceted catalog display:

- When presented with Library of Congress subject heading facets, would patrons use them?

- What problems would patrons have using facets?

- Would the use of LC subject headings in the faceted display be greater than use in nonfaceted display?

To answer these questions the authors conducted usability testing with Yale students to examine their attitudes and willingness to use subject heading facets. They also examined log files of two interfaces to the same backend Yale Library catalog: the non-faceted Orbis catalog and the faceted Yufind catalog interface.

The results of these examinations are important to libraries because they have experienced declining use of subject headings for years, while at the same time they have spent significant staff 
effort adding subject headings to catalog records. If faceted display is to be a successful means of improving subject heading use then librarians need a solid understanding of when and how patrons use facets.

\section{LITERATURE REVIEW}

Studies have noted patron difficulty using subject headings since the inception of online public access catalogs (OPACs). In the 1980's, as libraries began to offer OPACs, the Council on Library Resources surveyed patrons at 29 academic and public libraries about their searches in OPACs, and found patrons expressed dissatisfaction with subject searching and a desire for more ways of discovering subject headings (Matthews, Lawrence \& Ferguson 1983). Research has shown high failure rates for and patron dissatisfaction with subject searches (Cherry 1992, Moore 1981, Peters, Bell 2006) and general decrease in subject heading use (Larson 1991, Markey 1984).

As problems with subject search were recognized, researchers suggested ways to exploit subject heading information in ways that would fit well with how people search (Borgman 1996). One promising method to help library patrons with subject searches is faceted display of search results. Facets are subsets of search results based on some characteristic such as author, call number range or subject headings (Hearst, 2006). Non-library applications include FilmFinder (Shneiderman 2002), HiBrowse (Pollitt, Ellis \& Smith 1994) and Flamenco (Yee et al. 2003). At first facets were presented as search options to be combined in Boolean searches (parametric search), then as a way to browse a collection without searching (faceted navigation), and finally as a hybrid interface called faceted search in which the patron searches and then uses facets to refine a large set of results into manageable subsets (Tunkelang 2009). In 2007 Markey argued that results faceted by subject should help the searcher to see similarities among a wide set of results and then limit to a more precise set. It has been noted, however, that Library of Congress subject heading facets face particular obstacles because of the nature of how subject headings are created and applied to library records. For example, subject headings are formed with individual terms brought 
together to make more complex and specific headings. This specificity can lead to very long lists of values in the subject facet (McGrath 2007). Subject headings are not always formed consistently, further adding to the problem of long lists of subject facets which can be difficult for patrons to understand and navigate. Some solutions have been proposed, such as the FAST project, but are not yet widely used (Chan, O'Neill 2010). If Library of Congres subject headings are helpful to patrons in a faceted display, then patrons should adopt them and their use would be reflected in log files.

Research on facet use has been done in both library catalog and non-library specific faceted displays. In one non-library catalog study students were asked to use both the faceted Flamenco image database and a specially created non-faceted Baseline system. A majority preferred the faceted approach and reported that they learned more about the collection using the facets (Yee et al. 2003). The non-faceted display was not searchable and was not a production system, and perhaps was not a true comparison to a production level interface with facets. In an observational study of twelve graduate students in the humanities, Olson (2007) reported nine students were able to find material they previously had missed in a non-faceted library catalog of the same collection. These judgments relied on participants' memory of what they had seen in the other nonfaceted catalog. Other studies attempted to measure the extent to which facets were used in a production system. A large log file study of 130,000 searches at North Carolina State University's Endeca catalog found that $16 \%$ of searches used facets, and a smaller observational study at the same institution found $18 \%$ used facets (Kules et al. 2009, Lown 2008). In an eye-tracking test of the faceted union catalog Worldcat, seven participants showed little interest in facets, which were used more for known item searching than for topic searches (Prasse 2010). The question of how much facets will drive use of subject headings in comparison to non-faceted display remains an open question. 


\section{BACKGROUND}

Yale University is an academic research institution consisting of Yale College (undergraduate) and five graduate schools. The Yale University Library has 8 million records for items in the library stored and searchable in a Voyager catalog. In a previous study of its online public catalog Orbis, 3,777 recorded searches from December 2007 and March 2008 were selected at random and analyzed (Bauer, Peterson-Hart 2008). The most common search type was title (41.8\%) and the most common number of records returned for a search was zero (21.4\%). Subject headings were used in only $10.0 \%$ of searches, and when patrons tried to use the subject search function, as opposed to following a subject link, they typically used simple keywords which resulted in zero hits. In subsequent interviews with faculty and students it became clear that subject headings were mysterious and confusing to most. The poor performance of the online public access catalog represented an opportunity for the library to improve results for the patron, save their time, and help them discover library resources. A better search interface was needed which would function more like a Google search, with no need to understand field searching and controlled vocabularies.

Since January 2011 the Library has presented both the traditional Orbis interface and an open source SolrMarc-based search called Yufind, first developed at Villanova as Vufind. Both interfaces search the same material, but Yufind offers a more forgiving Google-like search, simpler displays of records and facets. Facets were desirable as a way to make subject headings more obvious and easier to use, and the hope was that patrons would discover and use subject headings more using the faceted interface.

\section{USABILITY TESTING}

Usability tests on the YuFind catalog interface were conducted in April 2008 and October 2009. In 2008, five undergraduate test participants were asked to complete 11 tasks, and to "think 
aloud" as they worked (a complete list of tasks and results is included in the Appendix). They each received a \$10 Barnes and Noble gift card for agreeing to participate in the study. The one-on-one sessions were followed by a series of debriefing questions. All sessions were recorded using Morae software for later analysis. Staff revisited usability testing in fall 2009 with five different undergraduate students and using the same kind of protocol (see the Appendix for a complete list of tasks and results).

In the first round of usability testing two tasks measured the students' use of facets by asking them to limit a list of search results by a narrower subtopic. Students were asked to search for books about the economic depression in the United States in the 1930's and then to find books within that set about health issues. Most (80\%) participants failed to complete this task. Even when participants tried to use subject heading facets the length of the list (more than thirty values listed) and extraneous topics rendered them difficult to navigate. At the same time, participants were intrigued by facets, and the potential was there for them to be useful.

Several changes were subsequently made to the display of facets in the sidebar. The sidebar was moved the left side of the screen, as is more common with retail sites. The list of facets was also reordered and categories relabeled. Most importantly, search was configured to return less irrelevant results, producing smaller lists of facet values which were also better related to the original search.

The usefulness of facets was much more evident in the second round of usability testing the following year. This time two tasks were designed specifically to test use of facets. The first task asked participants to limit a list of search results to a more narrowly defined topic. All participants quickly used the faceted topic display to help successfully refine the result set. The second task asked participants to find archival materials related to the 1919 Paris Peace Conference. Three out of the five participants were able to conduct a simple search and then narrow their results to a 
specific repository using facets. One student used advanced search, but was unsuccessful in finding the appropriate materials, while the fifth participant incorrectly selected a non-archival item from an initial simple search.

The positive results of these two tasks showed that most students used faceted displays to navigate results sets. Patron remarks during testing led the conclusion that providing faceted display would lead to more use of subject heading than we had found in traditional display. One student compared using the facets to the experience of online shopping, noting that, "In the same way that when I'm in the Amazon store, I know I can increase my ability to find stuff if I use them." Referring to this as "power-browsing", he commented that the catalog felt like "Barnes and Noble online." Another student praised the "more streamlined efficient searching." A third remarked: "I wish Orbis was like this to begin with-I think I'd use it more often."

\section{LOG FILE ANALYSIS}

During the six months January through May, 2011, both the traditional non-faceted Orbis display and faceted Yufind display were offered in production to the Yale community as equal entryways to the library's collection from http://library.yale.edu (see Figure 1).

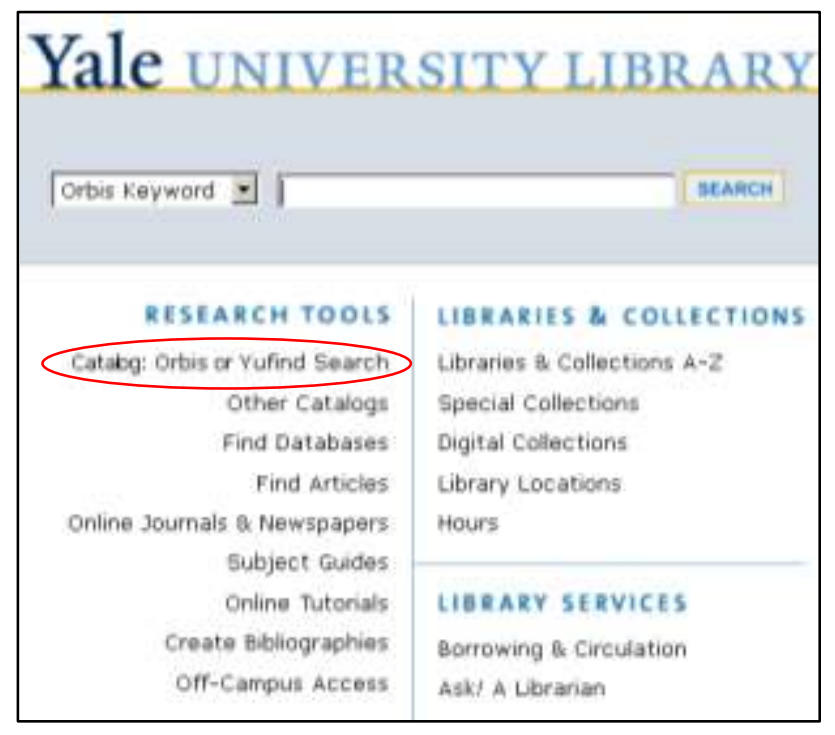


Figure 1. The home page of the Yale University Library web site, showing Orbis and Yufind as catalog interface options.

Yufind received 271,532 visits and 480,311 page views. A visit was equivalent to a person who came to the Yufind site and did one or more things, and each activity was counted as a page view. For example, a person who came to the site and executed a search, moved to a second page of results, and clicked on one record would be counted as one visit and three page views. The most frequent activity in Yufind was view of individual records (66.3\%), followed by general keyword search (24.1\%). Orbis was used 2.3 times as often as Yufind, with 632,445 visits in the same time period. In Orbis the breakdown of record views versus search was almost exactly reversed, so that search activity was three times more frequent than views of individual records. Search visits in Orbis occurred 8.3 times more often than in Yufind. The difference in type of activity appeared to be driven by traffic from Google to Yufind. Patrons discovered Yufind records in Google, followed the link to Yufind and viewed the record in Yufind. Yufind gives the library the option of allowing Google to crawl and index its XML encoded records, while Orbis does not.

\begin{tabular}{|l|l|l|l|l|}
\hline \multicolumn{1}{|c|}{ Activity } & Yufind Visits (\%) & \multicolumn{1}{|c|}{ Yufind Views (\%) } & \multicolumn{1}{|c|}{ Orbis Visits (\%) } & Orbis Views (\%) \\
\hline Record View & $207,438(76.4 \%)$ & $318,656(66.3 \%)$ & $127,095(20.1 \%)$ & $706,567(21.4 \%)$ \\
\hline Search & $41,882(15.4 \%)$ & $115,978(24.1 \%)$ & $348,341(55.1 \%)$ & $2,227,963$ \\
\hline Author & $21,998(8.1 \%)$ & $44,973(9.4 \%)$ & NA & NA \\
\hline Account & $212(<0.01 \%)$ & $700(0.1 \%)$ & $157,009(24.8 \%)$ & $320,688(9.7 \%)$ \\
\hline Total & $\mathbf{2 7 1 , 5 3 0}$ & $\mathbf{4 8 0 , 3 1 1}$ & $\mathbf{6 3 2 , 4 4 5}$ & $\mathbf{3 , 3 0 3 , 2 1 8}$ \\
\hline
\end{tabular}

Table 1. Breakdown of all activity in Yufind and Orbis, January 1 to May 31, 2011, measured in visits and page views.

\section{WHAT DO PATRONS DO AFTER RUNNING A SEARCH IN YUFIND?}

After a patron entered the Yufind interface they might have done nothing else, paged through results, looked at a record, executed a second search, or selected a facet to narrow the set of search results (Figure 2). 


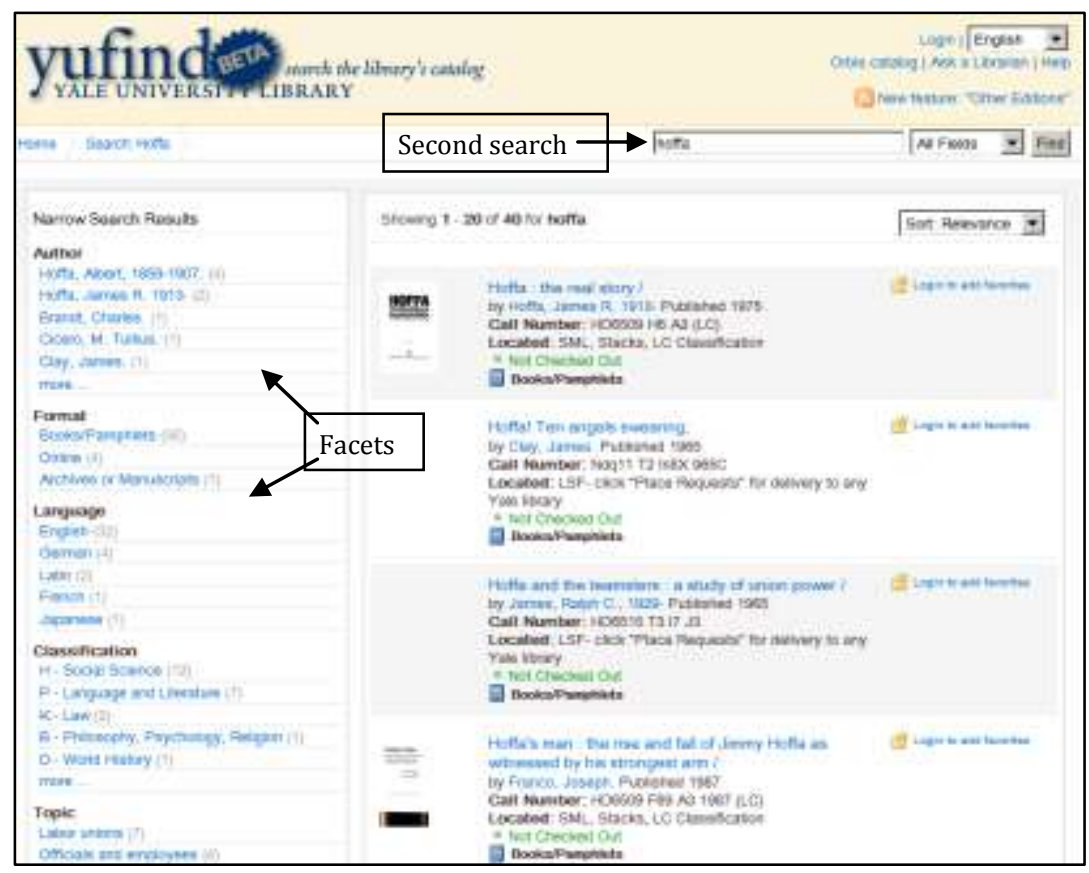

Figure 2. Results page in Yufind, showing facets, records, and search box.

Once a record was selected, a patron might have selected links within a record for author or subject heading (Figure 3).

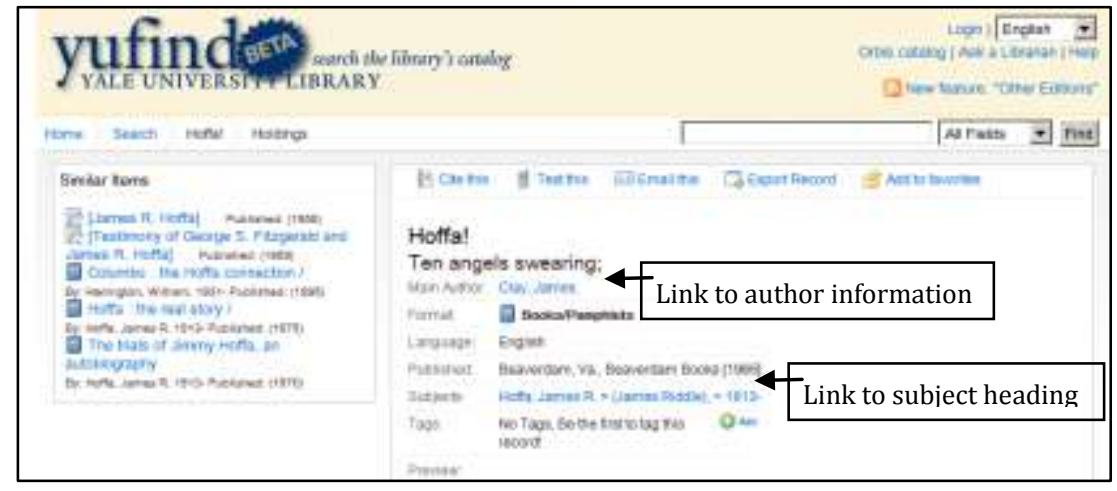

Figure 3. Indivdual Yufind record with links to author and subject headings.

During the six months studied, $34.8 \%$ of all search activity consisted of patrons following links from within a record, $27.7 \%$ of searches were second searches executed after an initial search, and in $25.4 \%$ of searches one or more facets were selected. The most commonly selected links were subject headings, which were chosen in $23.5 \%$ of searches. 
Yufind search results were displayed with these facets: author, classification, subject, language, and format type. The most frequently selected facet type was format $(31.0 \%$ of all facet use), followed by language (27.8\%) and subject (20.1\%). The most commonly selected facet values were language = "English," format = "books/pamphlets" and format = "online." The values of subject facets were drawn from the thousands of subject headings applied to Yale library catalog records and a diverse variety were selected by patrons, with only "united states" emerging as highly used.

\begin{tabular}{|r|r|r|}
\hline Facet Type & Count & $\begin{array}{l}\text { \% of facet use } \\
\text { (n=16,889) }\end{array}$ \\
\hline Format & 5232 & $31.0 \%$ \\
\hline Language & 4660 & $27.8 \%$ \\
\hline Subject & 3391 & $20.1 \%$ \\
\hline Author & 2381 & $14.1 \%$ \\
\hline Classification & 1186 & $7.0 \%$ \\
\hline Total & 16,889 & \\
\hline
\end{tabular}

Table 2. Use of facets in Yufind by type of facet, and expressed as a percentage of all facet use.

$25.2 \%$ of all searches included use of a facet, and $20.1 \%$ of those used subjects. Overall, $5.1 \%$ of searches used a subject heading facet. Together with following links, subject heading use accounted for $28.6 \%$ of Yufind search visit activity.

Orbis search logs were examined for the percentage of searches using subject headings. Subject headings were either selected as a search limit or followed from a link within records in $6.4 \%$ of all Orbis search visits.

\section{CONCLUSION}

The Yale Library has struggled with the interface to its catalog in recent years. Reviews of log files and usability testing have shown that many patrons, including undergraduate students, graduate students, and faculty, are perplexed by the catalog interface and how to use it to discover material. Yale experimented with the faceted catalog interface Yufind in an attempt to provide a better search experience and to promote use of subject headings. While Yufind has been offered on 
the main page of the Library's web site, it is still used far less than Orbis is. A marked difference between Orbis and Yufind was that Google drove traffic to Yufind in a way that was not possible in Orbis. The usefulness of Yufind may lie more in its ability to provide records to Google than in its faceted navigation. It is well documented that patrons start most information searches in Google and this study showed that holdings records in Google will be used and followed to the library's catalog. Putting library records in Google should be a priority.

Usability testing indicated that patrons were intrigued by and would use facets. Log file analysis confirmed this: patrons selected facets in $25.2 \%$ of all Yufind searches, lending credence to the use of facets as a way to expose metadata. Subject headings in Yufind were used more than subject headings in the non-faceted Orbis display $(28.6 \%$ of all searches versus $6.4 \%$ of Orbis searches) but the difference was caused by patrons following record links in Yufind more than by selecting subject heading facets. Given that facets in general are often used, but subject heading facets in particular see less use, there needs to be more consideration given to normalizing subject headings in a way that works better with a faceted navigation scheme. 


\section{APPENDIX}

Usability test questions, April 2008

\begin{tabular}{|c|c|c|}
\hline Question & $\begin{array}{l}\text { Yufind } \\
\text { Success } \\
\text { Rate }\end{array}$ & Notes \\
\hline $\begin{array}{l}\text { 1. You'd like to read Kagan's } \\
\text { Dangerous Nation. Does the Yale } \\
\text { Library have that book? }\end{array}$ & $100 \%$ & $\begin{array}{l}\text { All participants entered the title correctly and } \\
\text { Yufind performed correctly. }\end{array}$ \\
\hline 1a. Where is it? & $100 \%$ & $\begin{array}{l}\text { Location information is easy to see in Yufind, } \\
\text { but could be displayed more logically as Library } \\
\text { then Call Number. }\end{array}$ \\
\hline $\begin{array}{l}\text { 2. You need to find books about John } \\
\text { Adams for a paper you have to write. } \\
\text { Show me how you would do that. }\end{array}$ & $100 \%$ & $\begin{array}{l}\text { Implication: The ability to handle a search for } \\
\text { FIRSTNAME LASTNAME as well as LASTNAME, } \\
\text { FIRSTNAME is an improvement Yufind offers } \\
\text { over Orbis. }\end{array}$ \\
\hline $\begin{array}{l}\text { 2a. What would you do now if you } \\
\text { only wanted to see material written by } \\
\text { John Adams? }\end{array}$ & $20 \%$ & $\begin{array}{l}\text { Most participants failed to complete this task. } \\
\text { The use of the topic facet to narrow the search } \\
\text { was not understood by most participants, and } \\
\text { represents one of the hurdles of use of topic } \\
\text { facets. Even when participants tried to use topic } \\
\text { facets the length of the list and extraneous } \\
\text { topics rendered them less than useful. }\end{array}$ \\
\hline $\begin{array}{l}\text { 3. You need to find an article for a } \\
\text { class, and the professor has given you } \\
\text { this citation: Tuberculosis, non- } \\
\text { compliance and detention for the } \\
\text { public health. Journal of Medical } \\
\text { Ethics. } 2000 \text { Jun;26(3):157-9 Do we } \\
\text { have the journal? }\end{array}$ & $60 \%$ & $\begin{array}{l}\text { Some participants could do this task, but Yufind } \\
\text { failed to help the one person who did try } \\
\text { entering the article title. Also, the lack of a } \\
\text { journal title search from the basic search screen } \\
\text { caused confusion }\end{array}$ \\
\hline $\begin{array}{l}\text { 4. Find this book: The Logic of } \\
\text { Healthcare Reform. }\end{array}$ & $100 \%$ & $\begin{array}{l}\text { Participants were successful, and Yufind } \\
\text { performed well in finding this book whose title } \\
\text { was actually Health Care (with a space). }\end{array}$ \\
\hline 4a. Is it available? & $100 \%$ & Availability was easily recognized. \\
\hline 4b. How would you request it? & $100 \%$ & $\begin{array}{l}\text { Request option was easily recognized. However, } \\
\text { the option is not enabled yet, so this is really } \\
\text { not a complete success. }\end{array}$ \\
\hline $\begin{array}{l}\text { 4c. Can you find other books on the } \\
\text { same or a similar topic? }\end{array}$ & $60 \%$ & $\begin{array}{l}\text { Yufind offers several routes toward finding } \\
\text { related information. Only } 1 \text { person chose to use } \\
\text { the Related Items link, two used the subject } \\
\text { headings listed. Other participants who }\end{array}$ \\
\hline
\end{tabular}




\begin{tabular}{|l|l|l|}
\hline & & $\begin{array}{l}\text { examined related items didn't think they were } \\
\text { good matches. Yufind did not do particularly } \\
\text { better than Orbis, where a user could also click } \\
\text { on subject headings within a record. }\end{array}$ \\
\hline $\begin{array}{l}\text { 5. You are writing a paper about the } \\
\text { economic depression of the 1930's in } \\
\text { the United States. Can you find some } \\
\text { books on this subject? }\end{array}$ & $70 \%$ & $\begin{array}{l}\text { The Yufind search is overly broad and did not do } \\
\text { a particularly good job of relevancy ranking. } \\
\text { Topic facets were not helpful in this case. }\end{array}$ \\
\hline $\begin{array}{l}\text { 5a.Could you find books in this set of } \\
\text { results that are about health and } \\
\text { illness in the United States population, } \\
\text { or control of communicable diseases } \\
\text { during the era of the depression? }\end{array}$ & $20 \%$ & $\begin{array}{l}\text { The overly broad search results made this } \\
\text { difficult for participants. Again, topic facets } \\
\text { were difficult to navigate and not particularly } \\
\text { useful to this search. }\end{array}$ \\
\hline
\end{tabular}

Usability test questions, October 2009

\begin{tabular}{|c|c|c|}
\hline Question & $\begin{array}{c}\text { Success } \\
\text { Rate }(\mathrm{N}=5)\end{array}$ & Highlight \\
\hline $\begin{array}{l}\text { 1. a Suppose you would like to read } \\
\text { the book The Ordeal of Elizabeth } \\
\text { Marsh by Linda Colley. Does our } \\
\text { library have a copy of this book? }\end{array}$ & $100 \%$ & All completed this task successfully \\
\hline $\begin{array}{l}\text { 1.b Let's say you'd like to find out a bit } \\
\text { more about the book before you check } \\
\text { it out. What would you do? }\end{array}$ & $100 \%$ & $\begin{array}{l}\text { All clicked on the Description tab, } 4 \text { of } 5 \text { also } \\
\text { clicked on the Google Books preview link. } \\
\text { Physical description of the book was not } \\
\text { viewed positively; the Google Books } \\
\text { information was highly valued. Users were } \\
\text { drawn to the }\end{array}$ \\
\hline $\begin{array}{l}\text { 1.c If you wanted to use this book in a } \\
\text { bibliography you are creating, could } \\
\text { you find anything on this page to help } \\
\text { you? }\end{array}$ & $40 \%$ & $\begin{array}{l}\text { Only } 2 \text { clicked on the "Cite as" link; none } \\
\text { noticed the "Export to Refworks" link. The } \\
\text { student participants highly valued the } \\
\text { presentation of formatted citations. }\end{array}$ \\
\hline $\begin{array}{l}\text { 2. a Let's do a new search. You are } \\
\text { writing a paper on NASA. Can you find } \\
\text { some books on this subject? }\end{array}$ & $100 \%$ & All completed the task successfully \\
\hline $\begin{array}{l}\text { 2. b How could you quickly find a list of } \\
\text { books in this set of results that are }\end{array}$ & $100 \%$ & $\begin{array}{l}\text { All easily located and used the topic facets to } \\
\text { narrow the search }\end{array}$ \\
\hline
\end{tabular}




\begin{tabular}{|c|c|c|}
\hline specifically about space shuttles? & & \\
\hline $\begin{array}{l}\text { 3. Your professor has assigned a paper } \\
\text { on the } 1919 \text { Paris Peace Conference } \\
\text { that ended World War I. The } \\
\text { assignment requires that you use at } \\
\text { least one primary source (such as an } \\
\text { original diary or letter) from a } \\
\text { collection at Yale. You need to look at } \\
\text { the physical object-not a } \\
\text { reproduction or electronic version. } \\
\text { Can you use Yufind to locate these } \\
\text { kinds of materials? }\end{array}$ & $40 \%$ & $\begin{array}{l}\text { Three students used the "archive or } \\
\text { manuscript" facet to narrow the search, but } \\
\text { one did not recognize the results as useful. One } \\
\text { student selected non-archival material from the } \\
\text { search results. The last student used advanced } \\
\text { search, limiting to "archive or manuscript", but } \\
\text { also applied other limits that gave zero results. }\end{array}$ \\
\hline $\begin{array}{l}\text { 4. Let's go back to the search results } \\
\text { page and talk for a minute about the } \\
\text { categories in this sidebar. What does } \\
\text { the term "archive or manuscript" } \\
\text { mean to you? If you were given the } \\
\text { task of naming this category, would } \\
\text { you keep the current term or change } \\
\text { it? If you want to change the term, } \\
\text { what would you change it to? }\end{array}$ & $\mathrm{n} / \mathrm{a}$ & $\begin{array}{l}\text { Most participants seemed to instinctively } \\
\text { choose the Archive or Manuscript category as } \\
\text { the place to find primary sources, but many of } \\
\text { the participants seemed confused about what } \\
\text { would actually constitute a primary source- } \\
\text { could it be "papers" or books? }\end{array}$ \\
\hline $\begin{array}{l}\text { 5. If you wanted to look at a copy of } \\
\text { Jacob Abbott's History of Nero, how } \\
\text { would you get this book? }\end{array}$ & $40 \%$ & $\begin{array}{l}\text { Only two of the five participants were } \\
\text { completely successful in completing this task. } \\
\text { All participants scanned the results page } \\
\text { looking for a place request button. }\end{array}$ \\
\hline $\begin{array}{l}\text { 6. Let's say you're a student in English } \\
401 \text { and your professor has told you } \\
\text { that there are some books on reserve } \\
\text { that you need to read for the next few } \\
\text { classes. Could you use Yufind to find } \\
\text { information on where you can find } \\
\text { these books in the library? }\end{array}$ & $80 \%$ & $\begin{array}{l}\text { Four participants found the Course Reserves } \\
\text { link-2 attempted to search for the course title } \\
\text { first }\end{array}$ \\
\hline $\begin{array}{l}\text { 7. You are interested in reading the } \\
\text { book Mastering the Art of French } \\
\text { Cooking. Does the library have a copy } \\
\text { of this book? How would you get a } \\
\text { copy? }\end{array}$ & $40 \%$ & $\begin{array}{l}\text { Only two of the five participants clicked on the } \\
\text { Borrow Direct link at the bottom of the screen. } \\
\text { The other three participants were not aware of } \\
\text { the Borrow Direct service or the procedure for } \\
\text { requesting items through interlibrary loan }\end{array}$ \\
\hline $\begin{array}{l}\text { 8. a [Point out login link] What do you } \\
\text { think you would be logging in to here? }\end{array}$ & $\mathrm{n} / \mathrm{a}$ & $\begin{array}{l}\text { Participants had varying ideas about what login } \\
\text { might mean: access to one's library account, } \\
\text { bookbag-type function, or way to place }\end{array}$ \\
\hline
\end{tabular}




\begin{tabular}{|l|l|l|}
\hline $\begin{array}{l}\text { 8. b Would you ever use the tagging } \\
\text { feature? }\end{array}$ & $\mathrm{n} / \mathrm{a}$ & $\begin{array}{l}\text { requests. } \\
\text { None of the participants were experienced with } \\
\text { tagging items in other programs, but most } \\
\text { thought that it could be something that would } \\
\text { be useful if they had many items to organize for } \\
\text { a research project }\end{array}$ \\
\hline
\end{tabular}

Bauer, K. \& Peterson-Hart, A. 2008, Review of Orbis Search Activity 2007-2008, New Haven, CT.

Borgman, C.L. 1996, "Why are online catalogs still hard to use?", Journal of the American Society for Information Science, vol. 47, no. 7, pp. 493-503.

Cherry, J.M. 1992, "Improving Subject Access in OPACs: An Exploratory Study of Conversion of Users", Journal of Academic Librarianship, vol. 18, no. 2, pp. 95-99.

Kules, B., Capra, R., Banta, M. \& Sierra, T. 2009, "What do exploratory searchers look at in a faceted search interface?", Proceedings of the ACM/IEEE Joint Conference on Digital LibrariesACM, , pp. 313.

Larson, R.R. 1991, The decline of subject searching: Long-term trends and patterns of index use in an online catalog, -Wiley Subscription Services, Inc., A Wiley Company.

Lown, C. 2008, A transaction log analysis of NCSU's faceted navigation OPAC.

Markey, K. 1984, Subject searching in library catalogs :before and after the introduction of online catalogs, Online Computer Library Center, Dublin, Ohio.

Matthews, J.R., Lawrence, G.S. \& Ferguson, D. 1983, Using online catalogs: A nationwide survey, Neal-Schuman Publishers, Inc. New York, NY, USA.

Moore, C.W. 1981, "User Reactions to Online Catalogs: An Exploratory Study.", College and Research Libraries, vol. 42, no. 4, pp. 295-302.

Olson, T.A. 2007, "Utility of a faceted catalog for scholarly research", Library Hi Tech, vol. 25, no. 4 , pp. 550-561.

Peters, T. \& Bell, L. 2006, "Making OPACs Blow", Computers in Libraries, vol. 26, no. 8, pp. 20-22.

Pollitt, A.S., Ellis, G.P. \& Smith, M.P. 1994, "HIBROWSE for bibliographic databases", Journal of Information Science, vol. 20, no. 6, pp. 413-426. 
Prasse, M. 2010, The Use of Eye-Tracking to Evaluate the Effects of Format, Search Type, and Search Engine on the User's Processing of a Search Results Page., OCLC, Dublin, Ohio.

Shneiderman, B. 2002, "Dynamic queries for visual information seeking", Software, IEEE, vol. 11 , no. 6 , pp. 70-77.

Tunkelang, D. 2009, Faceted search, Morgan \& Claypool Publishers, [San Rafael, Calif.].

Yee, K.P., Swearingen, K., Li, K. \& Hearst, M. 2003, "Faceted metadata for image search and browsing", Proceedings of the SIGCHI conference on Human factors in computing systemsAssociation for Computing Machinery, , April 5-10, 2003, pp. 401. 